\title{
Al-Mo-Zn (Aluminum-Molybdenum-Zinc)
}

\section{Raghavan}

Recently, [2006Wan] determined an isothermal section for this ternary system at $450{ }^{\circ} \mathrm{C}$.

\section{Binary Systems}

The Al-Mo phase diagram [2006Eum] depicts the following intermediate phases: $\mathrm{MoAl}_{12}\left(\mathrm{Al}_{12} \mathrm{~W}\right.$-type cubic), $\mathrm{MoAl}_{5}(\mathrm{r})$ (rhombohedral, space group $R \overline{3} c$ ), $\mathrm{MoAl}_{5}\left(\mathrm{~h}^{\prime}\right)$ (hexagonal, $P 321$ ), $\mathrm{MoAl}_{5}(\mathrm{~h})$ (hexagonal, $P 6_{3} 22$ ), $\mathrm{Mo}_{5} \mathrm{Al}_{22}$ (orthorhombic, $F d d 2$ ), $\mathrm{Mo}_{4} \mathrm{Al}_{17}$ (monoclinic, C2), $\mathrm{MoAl}_{4}$ (monoclinic, $C m$ ), $\mathrm{MoAl}_{3}$ (monoclinic, $C 2 / m$ ), $\mathrm{Mo}_{3} \mathrm{Al}_{8}$ (monoclinic, $\mathrm{Cm}$ ), $\mathrm{Mo}_{37} \mathrm{Al}_{63}, \mathrm{MoAl}$ (bcc), and $\mathrm{Mo}_{3} \mathrm{Al}$ ( $A 15, \mathrm{Cr}_{3} \mathrm{Si}$-type cubic). In the Al-Zn system [Massaslski2],

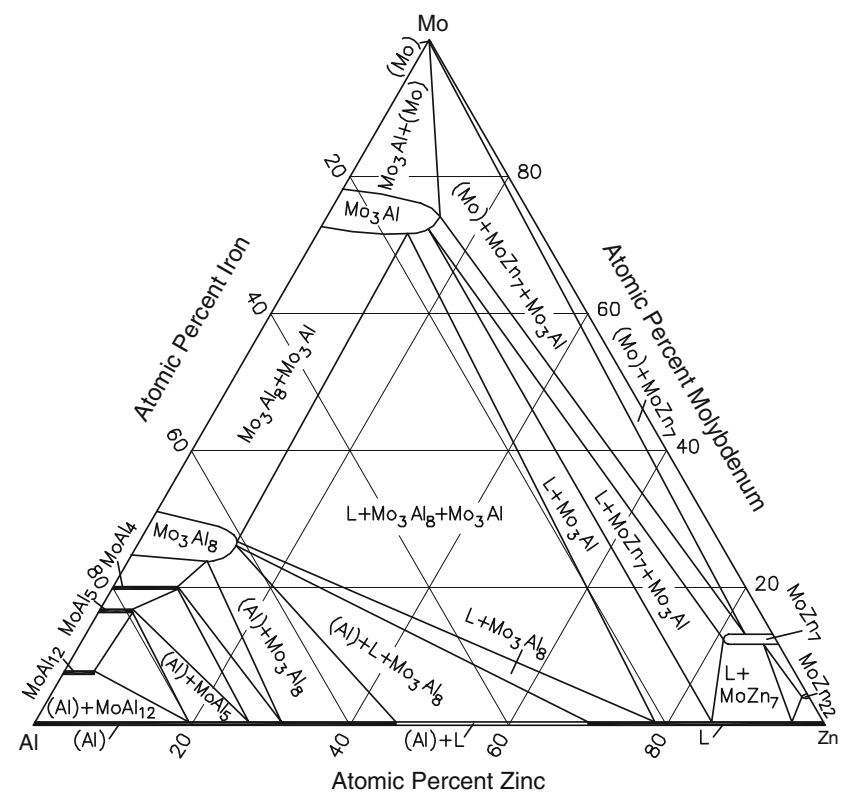

Fig. 1 Al-Mo-Zn isothermal section at $450{ }^{\circ} \mathrm{C}$ [2006Wan] solidification occurs through a eutectic reaction at $381{ }^{\circ} \mathrm{C}$ yielding $(\mathrm{Zn})$ and $(\mathrm{Al})$. On solidification, (Al) has more than 60 at. $\%$ of dissolved $\mathrm{Zn}$. At lower temperatures, this solid solution exhibits a miscibility gap, with a monotectoid reaction at $277^{\circ} \mathrm{C}:(\mathrm{Al})^{\prime} \leftrightarrow(\mathrm{Al})+(\mathrm{Zn})$. In the $\mathrm{Mo}-\mathrm{Zn}$ system [Massalski2], to intermediate phases $\mathrm{MoZn}_{22}$ (orthorhombic) and $\mathrm{MoZn}_{7}$ (Ca $\mathrm{Ca}_{7} \mathrm{Ge}$-type cubic) are stable below 463 and $575{ }^{\circ} \mathrm{C}$ respectively.

\section{Ternary Isothermal Section}

With starting metals of $99.99 \%$ purity, [2006Wan] melted 23 ternary alloys containing up to 40 at.\% Mo in evacuated quartz tubes at $1200{ }^{\circ} \mathrm{C}$. The alloys were given a final anneal at $460{ }^{\circ} \mathrm{C}$ for $20 \mathrm{~d}$ and quenched in water. The phase equilibria were studied with metallography, x-ray powder diffraction and energy dispersive x-ray analysis attached to the scanning electron microscope. The identified phases and their measured compositions were listed. The isothermal section at $460{ }^{\circ} \mathrm{C}$ constructed by [2006Wan] is shown in Fig. 1. The phase $\mathrm{MoAl}_{4}$ shown by [2006Wan] is presumably $\mathrm{Mo}_{4} \mathrm{Al}_{17}$ [2006Eum]. The equilibria involving $\mathrm{Mo}_{5} \mathrm{Al}_{22}$ are not known. The phases $\mathrm{MoAl}$ and $\mathrm{Mo}_{37} \mathrm{Al}_{63}$ are not stable at this temperature. The solubility of Mo in liquid $(\mathrm{Zn})$ and solid ( $\mathrm{Al}$ ) is negligible. $\mathrm{Mo}_{3} \mathrm{Al}$ and $\mathrm{Mo}_{3} \mathrm{Al}_{8}$ dissolve up to 11.5 and 13.5 at.\% $\mathrm{Zn}$ respectively. $\mathrm{MoZn}_{22}$ and $\mathrm{MoZn}_{7}$ dissolve up to 1 and 7 at.\% Al respectively. No ternary phases were found.

\section{References}

2006Eum: M. Eumann, G. Sauthoff, and M. Palm, Re-Evaluation of Phase Equilibria in the Al-Mo System, Int. J. Mater. Res., 2006, 97(11), p 1502-1511

2006Wan: Z. Wang, J. Wang, N.Y. Tang, Y.H. Liu, and X. Su, The $450{ }^{\circ} \mathrm{C}$ Isothermal Section of the Zn-Al-Mo Phase Diagram, J. Phase Equilib. Diffus., 2006, 27(5), p 469-476 